\section{Ordforklaringer}

Preeklampsi: Svangerskapsforgiftning forekommer hos $3-5 \%$ av alle fødende, men årsaken er uklar. Sykdommen kjennetegnes av høyt blodtrykk og protein i urinen hos kvinnen. I alvorlige tilfeller kan preeklampsi bli livstruende for både mor og barn. Eneste behandling er forløsning.

\title{
Risiko for svangerskapsforgiftning
}

\author{
Risikoen for svangerskapsforgiftning er høyere i første enn i senere \\ svangerskap, men den beskyttende effekten avtar dersom det går \\ lang tid mellom graviditetene.
}

Det er en av konklusjonene i Lill Trogstads avhandling Causes of preecklampsia. Hun har brukt data fra den norske mor-og-barnundersøkelsen og Medisinsk fødselsregister for å se nærmere på hva som påvirker risikoen for preeklampsi. Man vet at risikoen er størst i første svangerskap, 3-5\%, for så å avta i det andre - til 1,8\%.

- Våre studier viser at kvinner med preeklampsi i første svangerskap har større risiko (14\%) for å få det også i neste. Men vi undersøkte også

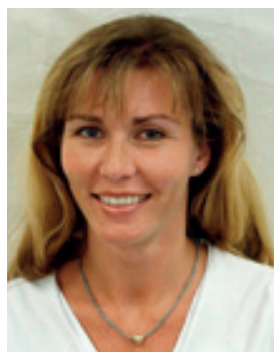

Lill Trogstad. Foto Unni Harsten hva som skjer dersom det går lang tid mellom svangerskapene, og fant at den beskyttende effekten ser ut til å avta med årene. Etter ti år er risikoen for preeklampsi like høy som den var ved første graviditet, sier Trogstad.
Effekten av dette tidsintervallet ser ikke ut til å gjelde for kvinner med preeklampsi i første svangerskap. Trogstad har også undersøkt risikoen i forhold til tidligere aborter og fertilitetsproblemer og fant en sammenheng.

- Tidligere provoserte aborter har beskyttende effekt, mens tidligere spontanaborter ikke har det. Tvert imot hadde kvinner med tre eller flere spontanaborter $50 \%$ øt risiko for preeklampsi. Dersom disse kvinnene i tillegg hadde vært behandlet for infertilitet, var risikoen to og en halv gang høyere enn hos kvinner uten aborter eller infertilitetsbehandling. Det kan tyde på at noen felles årsaksfaktorer kan ligge bak, sier Trogstad.

Hun disputerte for ph.d.-graden ved Universitetet i Oslo 2.10. 2009.

\section{Eline Feiring}

eline.feiring@legeforeningen.no

Tidsskriftet
Overføring av lapper: Friskt, levende vev tas fra en del av kroppen og overføres til et skadet område - ofte et område som har mistet fettvev, hud, muskler eller beinvev. Metoden som ble benyttet på Balkan kalles «pedicle flap transfer». For å behandle infeksjoner brukes «saphenous» og «suralis perforator flaps».

Se oversikt over doktoravhandlinger i seksjonen Oss imellom på side 2565

\section{Rekonstruktiv mikrokirurgi i krigssone}

\section{Rekonstruktiv mikrokirurgi og overføring av lapper for behandling av alvorlige skader i bein eller føtter kan utføres med enkelt utstyr under vanskelige forhold.}

Dette viser Nenad Tajsic i avhandlingen Limb salvage surgery. Studies of fasciocutaneous perforator flaps in post-traumatic reconstructions. Den første er en retrospektiv studie utført på Balkan i 1997 som omfattet 34 pasienter i alderen 8-40 år. Alle fikk store skader under krigen i 1993-96. Tajsic har selv operert dem.

- Vi valgte ut pasienter som kunne ha nytte av rekonstruktiv mikrokirurgi eller rekonstruksjon ved overføring av hudlapper. Operasjonene ble gjennomført ved et lite distriktssykehus med svært enkelt utstyr, og pasientene ble fulgt opp i tre måneder. Tre fikk komplikasjoner og ble operert på nytt. Studien er spesiell fordi den viser at mikrokirurgiske teknikker kan brukes med gode resultater selv under ekstremt vanskelige forhold- som for eksempel i en krigssituasjon. Men resultatene er også relevante for behandling av knivskader, skuddsår og liknende i fredstid, sier Tajsic.

Behandling av alvorlige posttraumatiske kroniske infeksjoner er en annen utfordring i rekonstruktiv kirurgi. Tajsic har behandlet 50 pasienter med alvorlige skader i nedre del av leggen og har vist at rekonstruktiv kirurgi med overføring av lapper samt bruk av forskjellige eksternfiksasjoner er godt egnet som behandlingsstrategi for pasienter som ellers har høy sykelighet.

Tajsic disputerte for ph.d.-graden ved Universitetet i Tromsø 26.5. 2009.

\section{Anne Forus}

anneforu@online.no

Tidsskriftet 